Review Article

\title{
An Overview of Important Ethnomedicinal Herbs of Phyllanthus Species: Present Status and Future Prospects
}

\author{
Bharti Sarin, ${ }^{1}$ Nidhi Verma, ${ }^{2}$ Juan Pedro Martín, ${ }^{3}$ and Aparajita Mohanty ${ }^{1}$ \\ ${ }^{1}$ Department of Botany, Gargi College, University of Delhi, Siri Fort Road, New Delhi 110049, India \\ ${ }^{2}$ National Bureau of Plant Genetic Resources, IARI Campus, New Delhi 110012, India \\ ${ }^{3}$ Departamento de Biologia Vegetal, Escuela Tecnica Superior de Ingenieros Agronomos, Universidad Politecnica de Madrid, \\ Ciudad Universitaria s/n, 28040 Madrid, Spain
}

Correspondence should be addressed to Aparajita Mohanty; aparajita.gargi@gmail.com

Received 29 August 2013; Accepted 30 October 2013; Published 3 February 2014

Academic Editors: R. Aroca, W. L. Morris, and S. Sakr

Copyright (C) 2014 Bharti Sarin et al. This is an open access article distributed under the Creative Commons Attribution License, which permits unrestricted use, distribution, and reproduction in any medium, provided the original work is properly cited.

\begin{abstract}
The genus Phyllanthus consists of more than 1000 species, of which many are used as traditional medicines. The plant extracts have been used since ancient times, for treating hypertension, diabetes, hepatic, urinary, and sexual disorders, and other common ailments. Modern day scientific investigations have now confirmed pharmacognostic properties of Phyllanthus herbs. The phytochemicals attributing these medicinal properties have been identified in many of the Phyllanthus herbs. The morphologically similar herbs of Phyllanthus grow together and admixture of species during collection for manufacture of herbal medicines is quite common. Hence, along with pharmacognostic and phytochemical studies, appropriate protocols for correct identification of species are also important. As the use of these herbs as green medicines is becoming more popular, it is imperative to assess its genetic diversity and phylogenetic relatedness for future conservation strategies. This review is an attempt to present an overview of the existing studies on pharmacognostics, phytochemistry, species identification, and genetic diversity of Phyllanthus herbs and consequently (i) highlight areas where further research is needed and (ii) draw attention towards extending similar studies in underutilized but potentially important herbs such as $P$. maderaspatensis, $P$. kozhikodianus, $P$. rheedii, P. scabrifolius, and P. rotundifolius.
\end{abstract}

\section{Introduction}

The genus Phyllanthus (Phyllanthaceae) consists of approximately 1000 species, spread over the American, African, Australian, and Asian continents [1,2]. All three major habits, that is, trees, shrubs, and herbs, are seen amongst the Phyllanthus species. Most of the herbs belonging to genus Phyllanthus have been shown to contain different combinations of secondary metabolites which render them with medicinal properties. The major class of bioactive compounds like alkaloids, flavonoids, lignans, phenols, tannins, and terpenes has been isolated from these herbs $[3,4]$.

Of a number of Phyllanthus herbs that are used all over the world as traditional herbal remedies, 12 important herbaceous species are discussed here. The species included are $P$. ajmerianus Rao and Choudhary, P. amarus Schum and
Thonn, $P$. debilis Klein ex Wild, $P$. fraternus Webster, $P$. kozhikodianus Sivadasan and Manilal, P. maderaspatensis L., $P$. rheedii Wight, $P$. rotundifolius Klein ex Wild, $P$. scabrifolius Hook.f., $P$. tenellus Roxb, $P$. urinaria L., and $P$. virgatus $\mathrm{G}$ Forst. Of these 12 species, $P$. ajmerianus is reported only from India [5]. All of these herbs, except $P$. ajmerianus, $P$. rotundifolius, and $P$. scabrifolius, have been scientifically investigated and proven to be of pharmacological value. The ethnic tribes of India and other Asian countries have used the herbs of Phyllanthus species since ancient times, as traditional home remedies. The decoctions of various parts of the herbs are used for treating hepatic, urinary, and sexually transmitted diseases, diabetes, hypertension, cancer, and wounds. Taking cue from the ethnic medications and potential of herbal treatments, the modern society is now eager to resort to green medicines which are without adverse side effects. Many of the Phyllanthus herbs form an integral 
part of Ayurveda, an Indian system of medicine. Considering the importance and potential of these herbs, it is natural that most of the studies are directed towards the phytochemical analysis and pharmacognostics (references detailed in Tables 1 and 2). However, for appropriate utilization of the herbs for ethnopharmacological investigations and preparation of herbal medicines, the correct identification of Phyllanthus species is very important. Also, with the growing utilization of these herbs in pharmaceutical industries, the risk of loss of genetic diversity exists. There are comparatively a lesser number of reports focusing on molecular taxonomy for identification of species and interspecific/intraspecific genetic diversity studies.

Keeping this present scenario in view, 12 important Phyllanthus herbs (P. ajmerianus, $P$. amarus, $P$. debilis, $P$. fraternus, P. kozhikodianus, $P$. maderaspatensis, $P$. rheedii, $P$. rotundifolius, $P$. scabrifolius, $P$. tenellus, $P$. urinaria, and $P$. virgatus) are reviewed with the following objectives: (i) to assess and hence direct efforts towards further studies on phytochemistry and pharmacognostics of the important herbs, (ii) to focus on the need to initiate studies of underresearched but potentially important medicinal herbs, and (iii) to assess the existing studies on identification of species, genetic diversity, and phylogeny, which will have an impact on formulating conservation strategies in future. The detailed assessment of clinical studies pertaining to the Phyllanthus herbs has not been elaborated in the present review.

\section{Pharmacognosy of Phyllanthus Herbs}

Of the 12 Phyllanthus herb species, nine species (P. amarus, $P$. debilis, $P$. fraternus, $P$. kozhikodianus, $P$. maderaspatensis, $P$. rheedii, $P$. tenellus, $P$. urinaria, and $P$. virgatus) have been scientifically analyzed whereas the remaining three species ( $P$. ajmerianus, $P$. rotundifolius, and $P$. scabrifolius) have not been investigated for their medicinal properties. The pharmacognostics of each of the nine herbs is discussed here.

2.1. P. amarus. This herb finds its use worldwide for treating problems of stomach, genitourinary system, liver, kidney, and spleen. It plays an important role in Ayurveda, an Indian system of medicine, and is used to treat jaundice, gastropathy, diarrhoea, dysentery, fevers, menorrhagia, scabies, genital infections, ulcers, and wounds [62]. Decoctions of whole plants are used for treating migraine, jaundice [63-65], gonorrhea and syphilis, skin disease, and malaria $[66,67]$. Paste of leaves or its decoction [68-72] and juice of roots [73] are used for treating jaundice. Chronic dysentery, menstrual problems, anorexia, urinary tract infection, and diabetes are also treated by leaf extract taken orally $[65,69,72,74]$. Extracts of the plant can prevent mutation of cells in the presence of chemical agents [75].

2.2. P. debilis. This herb shows antihepatotoxic [25] and anti-inflammatory [76] properties. Leaf juice is taken orally by the Kamar, Gond, and Halba tribes of Chattisgarh in India, for relief of problems related to sickle-cell anemia [77]. The aqueous extract of the plant shows antihyperglycemic property [78]. P. debilis has been shown to possess maximum antioxidant activity compared to $P$. amarus, $P$. maderaspatensis, $P$. urinaria, and P. virgatus [79].

2.3. P. fraternus. Traditionally, in India, the herb was used as a mild laxative, to expel worms and intestinal gas. The plant extracts are used for treating many types of biliary and urinary conditions like gall bladder, kidney stones, and bacterial infections such as cystitis, prostatitis, viral infections, hepatitis, flu, tuberculosis, liver diseases, anemia, veneral diseases, and urinary tract infections [80]. The antimicrobial property of $P$. fraternus has been reported by Chanda et al. [81]. The aqueous extract of the plant shows antioxidant property [82] and has protective effect against bromobenzene induced mitochondrial dysfunction [83]. Also the extract can reduce toxicity of drugs such as cisplatin and cyclophosphamide and therefore can be used to raise the therapeutic potential of anticancer drugs [84]. Ethanolic extract of the herb has antioxidant and anticoagulant property in experimental models [85]. According to Hukeri et al. [86], the flavonoids present in the herb show hypoglycemic effect in rats.

2.4. P. kozhikodianus. This herb provides protection to liver against chemical induced liver damage [87]. The herb was screened for hepatoprotective activity against liver damage induced by paracetamol in rats. Histological examination of liver confirmed hepatoprotective and antihepatotoxic properties [88].

2.5. P. maderaspatensis. Ethanolic extract of this herb demonstrated chemoprotective effect in modulating cisplatininduced nephrotoxicity and genotoxicity, thus proving its antioxidative property [89]. This extract is also taken as a popular dietary supplement in the southern part of India. It has been experimented as an ameliorative for adriamycininduced toxicity and oxidative stress in mice [90]. Whole plant extracts have shown antihepatotoxic, hepatoprotective, and choleretic activities $[88,91]$.

2.6. $P$. rheedii. The Muthuvan tribe of Kerala use all parts of this herb as a cure for liver diseases. The plant also shows hepatoprotective, antihyperglycemic, antihyperlipidemic, and antioxidant effects [92, 93].

2.7. P. tenellus. Extracts of fresh and dried plants have antiviral and antimicrobial activity $[94,95]$. The callus extracts of this herb have potential analgesic properties against neurogenic and inflammatory pain [96]. Although this herb is beneficial for diabetes and treatment of hepatitis, urolithiasis, and bowel diseases, it induces depression, spasms, increased respiratory rate, and dyspepsia, as shown from experiments on mice [97].

2.8. P. urinaria. This herb has multiple uses with many pharmacognostic properties. Aqueous/methanolic extract of whole plant is used for treating cancer [98-100]. The ethanolic extract of this herb has anti-inflammatory and antioxidant activity [31]. The acetone extract of the plant has been found 
to inhibit herpes simplex virus infection $[55,101]$. The plant parts have been successfully used in treating hypertension, jaundice, and diabetes [102]. Chloroform and methanolic extract have shown antibacterial activity against Helicobacter pylori, which causes peptic ulcers and gastric cancers [103]. Since $H$. pylori shows resistance to most antibiotics, this herb may be seriously studied for preparation of medicines against infections caused by this bacteria.

2.9. P. virgatus. In China, the extract of this herb is fed to children suffering from malnutrition due to worm infestation. This herb is used as an antiseptic and anti-inflammatory agent by the Gond tribe of India [104]. The plant extract shows high antioxidant property [105]. The lignin virgatusin is found in the plant parts and it inhibits growth of Grampositive bacteria [61].

Phyllanthus herbs with potential ethnomedicinal properties that have not been scientifically analyzed are as follows.

2.10. P. ajmerianus. This herb is found in Ajmer in India, and its identity has been confirmed by Vishwanatha et al. [5]. This plant has not been assessed for medicinal properties.

2.11. $P$. rotundifolius. This species has been analysed along with other Phyllanthus herbs for hepatoprotective property and it was found that $P$. urinaria and $P$. amarus have comparatively higher potential than $P$. rotundifolius [106]. There are no other reports on its pharmacognostic properties.

2.12. P. scabrifolius. The occurrence of this herb was reported in Karnataka, India [107]. This is an endemic species and scientific evaluation for its economic uses is yet to be done. However, local people use plant's decoction for treating chronic gonorrhea and dysentery and as a diuretic. The paste of seeds is used on wounds. Leaf paste is used on scabies and elephantitis and roots find its use in treating jaundice.

\section{Phytochemistry of Phyllanthus Herbs}

The major phytochemicals which have/may have a role in rendering the herbs with medicinal properties are listed in Table 1. Out of the 12 herbs reviewed, seven species (P. amarus, $P$. debilis, $P$. fraternus, $P$. maderaspatensis, $P$. tenellus, $P$. urinaria, and $P$. virgatus) have been reported to contain one or more classes of compounds such as lignans, flavonoids, tannins, and alkaloids.

Nahar et al. [4] have listed the various classes of phytochemicals found in Phyllanthus species. Of all the Phyllanthus herbs, the phytochemistry of P. amarus is well studied [62]. It has the maximum reports of pharmaceutically important compounds isolated from aqueous or organic solvent extracts. The lignans phyllanthin, hypophyllanthin, niranthin, nirtetralin, virgatusin, and heliobupthalmin lactone are common to $P$. amarus, $P$. maderaspatensis, $P$. urinaria, and $P$. virgatus [8]. However, according to Khatoon et al. [108], phyllanthin is absent in $P$. maderaspatensis. Also, Sharma et al. [106] have reported the absence of phyllanthin and hypophyllanthin from $P$. maderaspatensis and $P$. urinaria. In
P. fraternus, phyllanthin is absent, according to the studies of Khatoon et al. [108], whereas Tripathi et al. [26] have reported that both phyllanthin and hypophyllanthin are present in $P$. amarus and P. fraternus but the concentration of these two lignans varies substantially in the two species. Presence of the lignan, phyltetralin, is common to $P$. amarus, $P$. fraternus, $P$. maderaspatensis, $P$. virgatus, and $P$. urinaria (Table 1). The lignan hinokinin has been isolated from $P$. amarus, $P$. tenellus, and $P$. virgatus [10]. Flavonoids such as rutin, quercitrin, quercetin, kaempferol, and astragalin are present in both $P$. amarus and $P$. urinaria $[14,39]$. Presence of several ellagitannins such as geraniin, corilagin, and phyllanthusiins is also common to $P$. amarus as well as $P$. urinaria (Table 1 ).

To the best of our knowledge, there are no reports of isolation of any phytoconstituents from $P$. ajmerianus, P. kozhikodianus, $P$. rheedii, $P$. rotundifolius, and $P$. scabrifolius. These five herbs can be experimented for isolation and identification of pharmaceutically important phytochemicals.

3.1. Major Phytochemicals and Associated Pharmacological Activities. The phytochemicals with associated pharmacological activities of six Phyllanthus herbs (P. amarus, P. debilis, $P$. fraternus, $P$. tenellus, $P$. urinaria, and $P$. virgatus) are listed in Table 2.

The lignan phyllanthin renders hepatoprotective property to $P$. amarus [43]. However, $P$. fraternus, $P$. maderaspatensis, and $P$. urinaria do not contain phyllanthin $[106,108]$ but are hepatoprotective [106]. Therefore phyllanthin being the sole compound contributing to hepatoprotective property needs to be further investigated. Srirama et al. [109] also pointed out that phyllanthin and hypophyllanthin may not be the only compounds responsible for this property. According to Londhe et al. [52], hepatoprotective property of $P$. amarus is attributed to amariin and geraniin (which are ellagitannins), whereas phyllanthin and hypophyllanthin have been suggested to be anti-inflammatory and antiapoptotic [48].

Decalactone isolated from $P$. debilis is shown to possess antihepatotoxic ability [25]. The presence of this compound may be checked in other herb species which probably can throw light on potential of other Phyllanthus herbs as antihepatotoxic. Anticancer and/or antitumor properties have been related to the presence of phyllanthin, hypophyllanthin, niranthin, and polyphenols in $P$. amarus (Table 2). Of these three phytochemicals, niranthin is present in $P$. fraternus, $P$. maderaspatensis, $P$. urinaria, $P$. virgatus [8], and $P$. tenellus [10]. However, niranthin has not been investigated for anticancer potential in these herbs.

Antibacterial activity has been shown by phyllanthin and virgatusin in $P$. amarus. The lignin virgatusin from $P$. virgatus also shows antibacterial activity (Table 2). Virgatusin is present in $P$. maderaspatensis and P. urinaria as well (Table 1) and therefore the potential of this compound from these herbs can also be assessed for antibacterial activity. Antioxidant activity is shown by rutin, quercetin-3-O-glucoside (flavonoids), phyllanthin (lignan), amariin, repandusinic acid A, corilagin, phyllanthusiin A, B, C, geraniin (ellagitannins), methyl brevifolin (coumarin), methyl gallate, and trimethyl 1-3,4-dehydrochebulate (triterpenes) (see Table 2). Most of 
TABle 1: Major phytochemicals isolated from Phyllanthus amarus, $P$. debilis, $P$. fraternus, $P$. maderaspatensis, $P$. tenellus, $P$. urinaria, and $P$. virgatus.

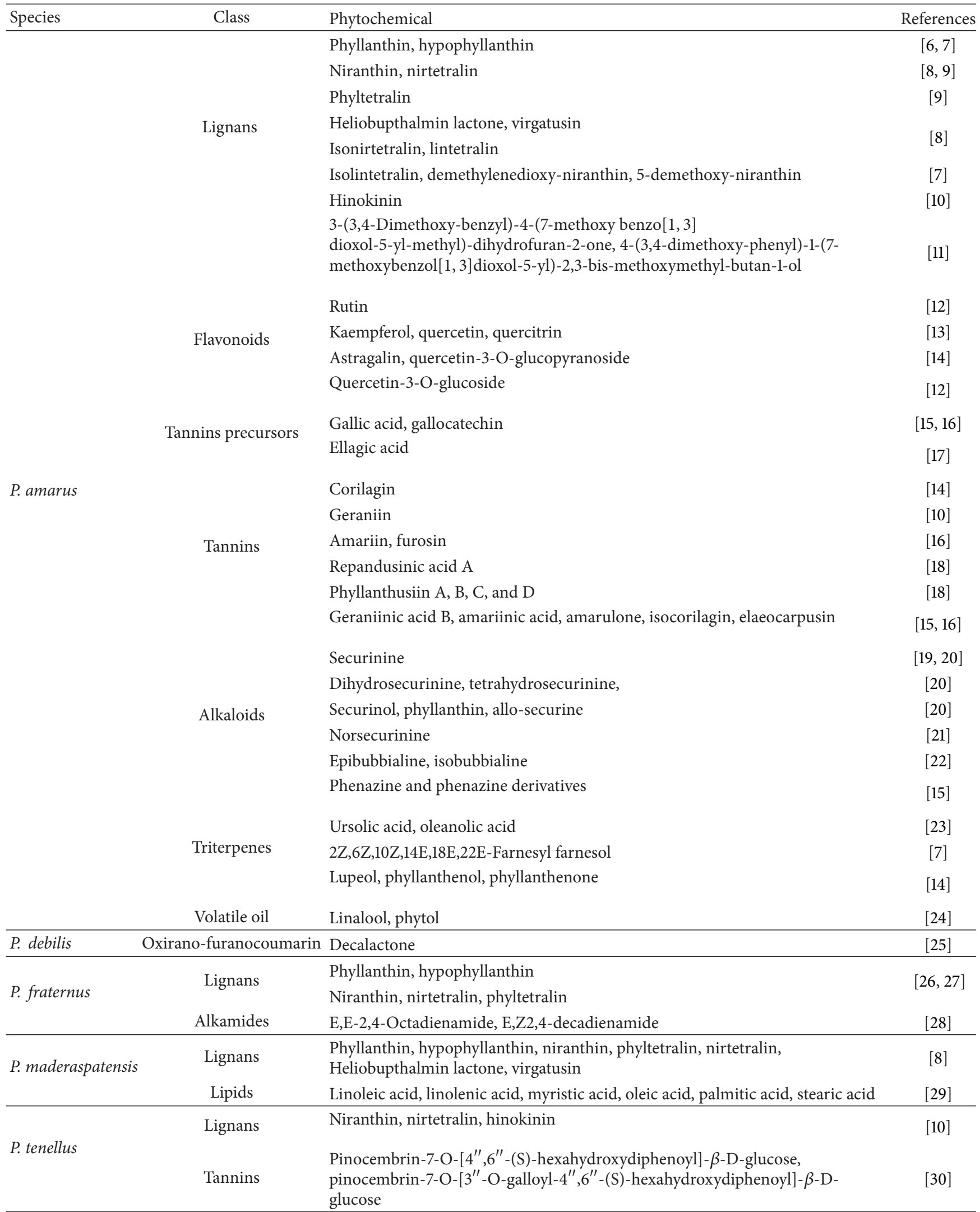


TABle 1: Continued.

\begin{tabular}{|c|c|c|c|}
\hline Species & Class & Phytochemical & References \\
\hline \multirow{18}{*}{ P. urinaria } & \multirow{4}{*}{ Lignans } & $\begin{array}{l}\text { Phyllanthin, hypophyllanthin, niranthin, nirtetralin, virgatusin, } \\
\text { heliobupthalmin lactone }\end{array}$ & {$[8]$} \\
\hline & & Phyltetralin & {$[31]$} \\
\hline & & 5-Demethoxyniranthin & {$[32]$} \\
\hline & & Lintetralin, urinatetralin, urinaligran, dextrobursehernin & [33] \\
\hline & \multirow{5}{*}{ Ellagitannin } & Geraniin & {$[34]$} \\
\hline & & Ellagic acid & [35-37] \\
\hline & & Corilagin & {$[36,38]$} \\
\hline & & Phyllanthusiin U & {$[36]$} \\
\hline & & Gallic acid & {$[35]$} \\
\hline & \multirow{2}{*}{ Flavonoid } & Quercitrin, rutin, astragalin, quercetin, isoquercitrin, kaempferol & [39] \\
\hline & & Rhamnocitrin & {$[31]$} \\
\hline & Acid & Hexacosanoic acid & {$[40]$} \\
\hline & Alkanol & Triacontanol & {$[40]$} \\
\hline & Phytallate & Phyllester & {$[40]$} \\
\hline & Sterol & $\beta$-Sitosterol, daucosterol & [35] \\
\hline & \multirow{2}{*}{ Triterpenes } & $\beta$-Amyrin, lupeol acetate & \multirow{2}{*}[31,40]{} \\
\hline & & Methyl gallate, trimethyl 1-3,4 dehydrochebulate & \\
\hline & Coumarin & Methyl brevifolin carboxylate & {$[31]$} \\
\hline \multirow{6}{*}{ P. virgatus } & \multirow[t]{2}{*}{ Lignans } & $\begin{array}{l}\text { Phyllanthin, hypophyllanthin, niranthin, nirtetralin, heliobupthalmin lactone, } \\
\text { virgatusin }\end{array}$ & {$[8]$} \\
\hline & & $\begin{array}{l}\text { Hinokinin, isolintetralin, phyltetralin, } \\
(+)-8-3,4 \text {-methylenedioxybenzyl- } 8^{\prime}-\left(3^{\prime}, 4^{\prime} \text {-dimethoxybenzyl)-butyrolactone }\right.\end{array}$ & {$[41]$} \\
\hline & Tannins & Virgatyne, virganin, norlignan & {$[42]$} \\
\hline & Ellagitannins & Geraniin & {$[10]$} \\
\hline & Flavonoid sulfonates & $\begin{array}{l}\text { Galanin-8-sulfonate, galanin-3-O-beta-D-glucoside-8-sulfonate, } \\
\text { Kaempferol-8-sulfonate }\end{array}$ & {$[42]$} \\
\hline & Acid & Indole-3-carboxylic acid & [41] \\
\hline
\end{tabular}

the compounds have been investigated in $P$. amarus for antioxidant property. Rutin and quercetin are found in $P$. urinaria but have been shown to exhibit antiviral property [31]. It may be worthwhile to investigate the role of rutin and quercetin for antioxidant property in P. urinaria and for antiviral property in $P$. amarus.

In separate studies, the antiviral property of $P$. amarus has been attributed to the compounds niranthin, nirtetralin, hinokinin, geraniin, and corilagin [10, 51]. The antiviral activity in $P$. tenellus and $P$. virgatus is also attributed to niranthin, nirtetralin, and hinokinin [10]. Geraniin is the common compound found in $P$. amarus, $P$. urinaria, and $P$. virgatus, which shows antiviral property in the three herbs $[10,55]$. Anti-inflammatory activity in $P$. urinaria is attributed to the phytochemicals, phyltetralin, phyllanthin, quercetin, rutin, rhamnocitrin, and $\beta$-sitosterol $[31,59]$. These compounds are found in other Phyllanthus herbs also (Table 1) and therefore the herbs can be assessed for anti-inflammatory property. Some of the flavonoids (rutin and quercetin-3-Oglucoside) and ellagitannins (geraniin, amariin, repandusinic acid, corilagin, and phyllanthusiin) in $P$. amarus have a role in radioprotective property (Table 2 ). Since most of these compounds are also present in P. urinaria (Table 1), the role of these phytochemicals in contributing radioprotective property in this herb can be investigated.

The alkaloid norsecurinine is associated with antifungal property of $P$. amarus and the compounds, $\beta$-sitosterol and $\beta$ amyrin, are associated with analgesic property of $P$. urinaria (Table 2). Two alkamides (E,E-2,4-octadienamide and E,Z2,4-decadienamide) have been isolated from $P$. fraternus which contributes to the antiplasmodial property of the herb (Table 2). This is another pharmaceutically very relevant property that can be investigated for potential antimalaria drugs.

In the six herbs (i.e., $P$. ajmerianus, $P$. kozhikodianus, $P$. maderaspatensis, $P$. rheedii, $P$. rotundifolius, and $P$. scabrifolius), to the best of our knowledge, there are no studies correlating a phytochemical with its pharmaceutical property. The plant extracts of $P$. kozhikodianus and $P$. rheedii have been analysed for pharmacognostic properties and P. kozhikodianus is shown to be hepatoprotective $[87,88]$ and $P$. rheedii to have antihyperglycemic, antihyperlipidemic, and antioxidant 
TABle 2: Pharmacological effect of major phytochemicals in Phyllanthus amarus, P. debilis, P. fraternus, P. tenellus, P. urinaria, and P. virgatus.

\begin{tabular}{|c|c|c|c|c|}
\hline Species & Class & Phytoconstituent & Pharmacological effect & Reference \\
\hline \multirow[t]{36}{*}{ P. amarus } & Lignan & Phyllanthin & Hepatoprotective & [43] \\
\hline & & & Anticancer, antitumour & {$[44]$} \\
\hline & & & Antileukemia & {$[45]$} \\
\hline & & & Antibacterial & {$[46]$} \\
\hline & & & Antiamnestic & {$[47]$} \\
\hline & & & Antiaging & \\
\hline & & & Antioxidant & {$[6]$} \\
\hline & & & $\begin{array}{l}\text { Anti-inflammatory, } \\
\text { antiapoptotic }\end{array}$ & {$[48]$} \\
\hline & & Hypophyllanthin & Antitumor, anticancer & {$[44]$} \\
\hline & & Niranthin & Antitumor & {$[20]$} \\
\hline & & & Antiviral & {$[10]$} \\
\hline & & & Anti-inflammatory & {$[9]$} \\
\hline & & Phyltetralin & Anti-inflammatory & {$[9]$} \\
\hline & & Nirtetralin & Anti-inflammatory & {$[9]$} \\
\hline & & & Antiviral & {$[10]$} \\
\hline & & & $\begin{array}{l}\text { Reverses multidrug } \\
\text { resistance }\end{array}$ & {$[49,50]$} \\
\hline & & Hinokinin & Antiviral & {$[10]$} \\
\hline & Flavonoid & Rutin & Radioprotective & {$[12]$} \\
\hline & & & Antioxidant & {$[18]$} \\
\hline & & Quercetin-3-O-glucoside & Antioxidant & {$[18]$} \\
\hline & Tannin & Geraniin & Antiviral & {$[10,51]$} \\
\hline & & & Radioprotective & {$[12]$} \\
\hline & & & Hepatoprotective & {$[52]$} \\
\hline & & Amariin & Antioxidant & {$[18]$} \\
\hline & & & Radioprotective & {$[12]$} \\
\hline & & & Hepatoprotective & {$[52]$} \\
\hline & & Repandusinic acid A & Antioxidant & {$[18]$} \\
\hline & & & Radioprotective & {$[12]$} \\
\hline & & Corilagin & Antioxidant & {$[18]$} \\
\hline & & & Radioprotective & {$[12]$} \\
\hline & & & Antiviral & {$[51]$} \\
\hline & & Phyllanthusiin A, B, C, D & Antioxidant & {$[18]$} \\
\hline & & & radioprotective & {$[12]$} \\
\hline & Alkaloid & Norsecurinine & Antifungal & {$[21]$} \\
\hline & Volatile oil & Linalool, phytol & Antimicrobial & {$[24,53]$} \\
\hline & Polyphenol & & Anticancer & {$[54]$} \\
\hline \multirow[t]{2}{*}{ P. fraternus } & Alkamide & E,E-2,4-Octadienamide & Antiplasmodial & {$[28]$} \\
\hline & & E,Z-2,4-Decadienamide & Antiplasmodial & [28] \\
\hline P. debilis & Oxirano-furanocoumarin & Debelalactone & Antihepatotoxic & [25] \\
\hline \multirow[t]{3}{*}{ P. tenellus } & Lignan & Niranthin & Antiviral & {$[10]$} \\
\hline & & Nirtetralin & Antiviral & {$[10]$} \\
\hline & & Hinokinin & Antiviral & {$[10]$} \\
\hline
\end{tabular}


TABLE 2: Continued.

\begin{tabular}{|c|c|c|c|c|}
\hline Species & Class & Phytoconstituent & Pharmacological effect & Reference \\
\hline \multirow[t]{15}{*}{ P. urinaria } & Lignan & Phyltetralin & Anti-inflammatory & {$[31]$} \\
\hline & & Phyllanthin & Anti-inflammatory & {$[31]$} \\
\hline & Flavonoid & Quercetin & Anti-inflammatory & {$[31]$} \\
\hline & & Rutin & Anti-inflammatory & {$[31]$} \\
\hline & & Rhamnocitrin & Anti-inflammatory & {$[31]$} \\
\hline & Coumarin & Methylbrevifolin carboxylate & Antioxidant & {$[31]$} \\
\hline & Ellagitannin & Geraniin & Antiviral & {$[55]$} \\
\hline & & & Antioxidant & {$[56]$} \\
\hline & & Ellagic acid & Antiangiogenic & {$[57]$} \\
\hline & & & Antiviral & [37] \\
\hline & Sterol & $\beta$-Sitosterol & Analgesic & {$[58]$} \\
\hline & & & Anti-inflammatory & [59] \\
\hline & Triterpene & $\beta$-Amyrin & Analgesic & {$[60]$} \\
\hline & & Methyl gallate & Antioxidant & {$[31]$} \\
\hline & & Trimethyl 1-3,4 dehydrochebulate & Antioxidant & {$[31]$} \\
\hline \multirow[t]{5}{*}{ P. virgatus } & Lignan & Niranthin & Antiviral & {$[10]$} \\
\hline & & Nirtetralin & Antiviral & {$[10]$} \\
\hline & & Hinokinin & Antiviral & {$[10]$} \\
\hline & & Virgatusin & Antibacterial & {$[61]$} \\
\hline & Ellagitannin & Geraniin & Antiviral & {$[10]$} \\
\hline
\end{tabular}

effects [92, 93]. However, the compounds responsible for these pharmaceutical properties have not been identified. $P$. ajmerianus, $P$. rotundifolius, and $P$. scabrifolius have not been researched at all for either phytochemicals or pharmacological properties.

\subsection{Phytochemicals with Multiple Pharmaceutical Properties.} The lignan phyllanthin has been shown to possess maximum number of medicinal properties such as hepatoprotective, anticancer, antiamnestic, antiaging, antioxidant, and anti-inflammatory (Table 2). All these properties (except anti-inflammatory which is shown in $P$. urinaria) have been assessed in $P$. amarus. Another lignan, niranthin, is shown to have both antitumor and antiviral property. The flavonoids (rutin and quercetin-3-O-glucoside) and ellagitannins (geraniin, amariin, repandusinic acid, corilagin, and phyllanthusiin) have antioxidant as well as radioprotective property (Table 2).

\section{Studies on Genetic Diversity, Species Identification, and Phylogeny}

Genetic diversity studies, phylogenetics, identification of species, and characterization of germplasm are very important for appropriate utilization and conservation of plant genetic resources. The total number of genetic diversity studies on herbs of Phyllanthus is few, compared to pharmacognostic/pharmacological studies. The extent of genetic diversity has been investigated in $P$. amarus, $P$. debilis, and $P$. virgatus using RAPD (random amplified polymorphic DNA) and ISSR (Intersimple sequence repeats) markers, and an average polymorphism of $68.2 \%$ and $69.7 \%$, respectively, was observed [110]. Genetic diversity analysis using RAPD markers, within $P$. amarus collected from different geographical locations in India, showed that the accessions from the southern part of India have high intrapopulation variation [111]. This variation may be attributed to the cross-pollination mechanisms in populations and also because they grow as weeds without much anthropogenic intervention [112].

Isozymes also have been used to assess the genetic variability in south Indian populations of $P$. amarus to identify superior genotypes for improving drug quality and for formulating strategies for in situ conservation and sustainable utilization [113]. Ravikant et al. [114] have also described southern India to be the genetic hot spot of Phyllanthus sp.

The ethnomedicinal uses and pharmacological activities among $P$. amarus, $P$. fraternus, $P$. debilis, and $P$. urinaria are varied but these plant species commonly grow together in the same open habitats and wastelands. In Bangladesh, China, India, Pakistan, and Thailand, P. amarus, P. fraternus, $P$. debilis, and P. urinaria grow together and lead to confusion in identification of these herbaceous species. Systematic studies on herbaceous Phyllanthus species, using morphological and anatomical parameters, could identify these Phyllanthus herbs [115]. Earlier, P. amarus, P. fraternus, and P. debilis were grouped under the single species named $P$. niruri and were later mentioned as species of "niruri complex." Now, it is 
clarified that $P$. niruri is an American species and not at all found in India. Hence, the species identified as $P$. niruri is actually $P$. amarus, $P$. fraternus, and/or $P$. debilis $[112,116]$.

The use of molecular markers for identification of Phyllanthus species has proved to be a reliable tool. Speciesspecific SCAR (sequence characterized amplified regions) markers were developed for identification of Phyllanthus species ( $P$. amarus, $P$. fraternus, $P$. debilis, and $P$. urinaria) used in dry leaf bulk trade $[117,118]$. Bandyopadhyay and Raychaudhuri [119] compared RAPD, SCAR, and AFLP (amplified fragment length polymorphism) markers for identification of five Phyllanthus spp. and concluded that AFLP is a better polymorphic marker. Senapati et al. [120] identified species-specific diagnostic markers for ten Phyllanthus species, using intersimple sequence repeat-polymerase chain reaction (ISSR-PCR). Srirama et al. [121] assessed species admixtures in raw drug trade of Phyllanthus using DNA barcoding tools. They analyzed sequence variations of $p s b \mathrm{~A}-\operatorname{trn} \mathrm{H}$ region of the chloroplast to identify the Phyllanthus species present in the admixtures. AFLP profile along with morphological study could confirm the identification of $P$. ajmerianus Chaudhary and Rao in Ajmer, India [5]. The study also pointed to the distinct characteristic of the taxon and close relatedness to $P$. kozhikodianus and $P$. rheedii. PCRRFLP approach of ITS (internal transcribed spacers) region has been successful in discriminating P. amarus, $P$. debilis, and P. urinaria [122].

Bandyopadhyay and Raychaudhuri [123] sequenced ITS regions of five species of Phyllanthus. The ITS sequences generated phylograms which aided in deducing affinities among $P$. emblica, $P$. reticulatus, $P$. amarus, $P$. fraternus, and $P$. urinaria. Phylogenetic relationships of 23 Phyllanthus species of Thailand have been analysed by sequencing ITS regions [122]. RAPD and ISSR markers have also been used to analyse phylogenetic relationship between twelve species of Phyllanthus [124].

\section{Conclusions and Future Prospects}

There are practically no studies on pharmacognostics and identification and/or isolation of pharmaceutically important compounds in $P$ ajmerianus, $P$. rotundifolius, and $P$. scabrifolius. Considering the medicinal properties of the Phyllanthus herbs, these species should be assessed for pharmacognostics and pharmacological properties. In case of $P$. maderaspatensis, $P$. kozhikodianus, and $P$. rheedii, although pharmacognostic properties are known, the compounds responsible for such properties have not been identified. Therefore these herbs can be experimented for isolation and identification of phytochemicals, based on existing knowledge of compounds observed in other Phyllanthus herbs and subsequently can be used for preparation of herbal medicines. Studies on pharmacognosy and pharmaceutical activity of phytochemicals published under the identity of $P$. niruri may be reevaluated especially the studies from India, as now it is confirmed that $P$. niruri is not found in India [112]. The studies, mentioning $P$. niruri, actually may be of $P$. amarus, $P$. fraternus, or P. debilis. Also, to our knowledge, there are either few or no studies on genetic diversity of most Phyllanthus herb species, some of which are endemic species with a few populations, for example, P. scabrifolius in India. Considering the growing popularity of ethnopharmacological value of Phyllanthus species and its use in herbal medicines, it is imperative to assess the genetic diversity of these species, which will have implications for formulating conservation strategies in future.

\section{Conflict of Interests}

The authors declare that there is no conflict of interests regarding the publication of this paper.

\section{Acknowledgment}

The funding provided by Department of Science and Technology (DST), Ministry of Science and Technology, India, is gratefully acknowledged.

\section{References}

[1] D. W. Unander, G. L. Webster, and B. S. Blumberg, "Usage and bioassays in Phyllanthus (Euphorbiaceae)-IV: clustering of antiviral uses and other effects," Journal of Ethnopharmacology, vol. 45, no. 1, pp. 1-18, 1995.

[2] G. L. Webster, "Synopsis of the genus and suprageneric taxa of Euphorbiaceae," Annals of the Missouri Botanical Garden, vol. 81, pp. 33-144, 1994.

[3] J. B. Calixto, A. R. S. Santos, V. C. Filho et al., "A review of the plants of the Genus Phyllanthus: their chemistry, pharmacology and therapeutic potential," Medicinal Research Reviews, vol. 18, no. 4, pp. 225-258, 1998.

[4] L. Nahar, S. D. Sarker, and A. Delazar, "Phytochemistry of the genus Phyllanthus," in Phyllanthus Species: Scientific Evaluation and Medicinal Applications, R. Kuttan and K. B. Harikumar, Eds., pp. 119-138, Taylor and Francis Group, CRC Press, London, UK, 2011.

[5] V. Vishwanatha, T. N. Parameswaran, R. R. Rao et al., "Reconfirmation of the identity and occurrence of Phyllanthus ajmerianus Chaudhary \& Rao in Ajmer, Rajasthan, India," Current Science, vol. 91, no. 1, pp. 24-26, 2006.

[6] R. Krithika, R. Mohankumar, R. J. Verma et al., "Isolation, characterization and antioxidative effect of phyllanthin against CCl4-induced toxicity in HepG2 cell line," Chemico-Biological Interactions, vol. 181, no. 3, pp. 351-358, 2009.

[7] M. A. M. Maciel, A. F. Cunha, N. T. C. Dantas et al., "NMR characterization of bioactive lignans from Phyllanthus amarus Schum and Thonn," Journal of Magnetic Resonance Imaging, vol. 6, no. 3, pp. 76-82, 2007.

[8] K. Shanker, M. Singh, V. Srivastava, R. Verma, A. Gupta, and M. Gupta, "Simultaneous analysis of six bioactive lignans in Phyllanthus species by reversed phase hyphenated high performance liquid chromatographic technique," Acta Chromatographica, vol. 23, no. 2, pp. 321-337, 2011.

[9] C. A. L. Kassuya, D. F. P. Leite, L. V. De Melo, V. L. C. Rehder, and J. B. Calixto, "Anti-inflammatory properties of extracts, fractions and lignans isolated from Phyllanthus amarus," Planta Medica, vol. 71, no. 8, pp. 721-726, 2005. 
[10] R.-L. Huang, Y.-L. Huang, J.-C. Ou, C.-C. Chen, F.-L. Hsu, and C. Chang, "Screening of 25 compounds isolated from Phyllanthus species for anti-human hepatitis B virus in vitro," Phytotherapy Research, vol. 17, no. 5, pp. 449-453, 2003.

[11] M. Singh, N. Tiwari, K. Shanker, R. K. Verma, A. K. Gupta, and M. M. Gupta, "Two new lignans from Phyllanthus amarus," Journal of Asian Natural Products Research, vol. 11, no. 6, pp. 562-568, 2009.

[12] J. S. Londhe, T. P. A. Devasagayam, L. Y. Foo, and S. S. Ghaskadbi, "Radioprotective properties of polyphenols from Phyllanthus amarus Linn," Journal of Radiation Research, vol. 50, no. 4, pp. 303-309, 2009.

[13] S. P. Thyagarajan and S. Jayaram, "Natural History of Phyllanthus amarus in treatment of hepatitis B," Indian Journal of Medical Microbiology, vol. 10, no. 2, pp. 64-80, 1992.

[14] L. Yeap Foo and H. Wong, "Phyllanthusiin D, an unusual hydrolysable tannin from Phyllanthus amarus," Phytochemistry, vol. 31, no. 2, pp. 711-713, 1992.

[15] L. Y. Foo, "Amarulone, a novel cyclic hydrolysable tannin from Phyllanthus amarus," Natural Product Letters, vol. 3, no. 1, pp. 45-52, 1993.

[16] L. Y. Foo, "Amariinic acid and related ellagitannins from Phyllanthus amarus," Phytochemistry, vol. 39, no. 1, pp. 217-224, 1995.

[17] K. Dhalwal, Y. S. Biradar, and M. Rajani, "High-performance thin-layer chromatography densitometric method for simultaneous quantitation of phyllanthin, hypophyllanthin, gallic acid, and ellagic acid in Phyllanthus amarus," Journal of AOAC International, vol. 89, no. 3, pp. 619-623, 2006.

[18] J. S. Londhe, T. P. A. Devasagayam, L. Y. Foo, and S. S. Ghaskadbi, "Antioxidant activity of some polyphenol constituents of the medicinal plant Phyllanthus amarus Linn," Redox Report, vol. 13, no. 5, pp. 199-207, 2008.

[19] A. K. Singh, M. B. Pandey, S. Singh et al., "Antifungal activity of securinine against some plant pathogenic fungi," Mycobiology, vol. 36, no. 2, pp. 99-101, 2008.

[20] C. A. L. Kassuya, A. Silvestre, O. Menezes-de-Lima Jr., D. M. Marotta, V. L. G. Rehder, and J. B. Calixto, "Antiinflammatory and antiallodynic actions of the lignan niranthin isolated from Phyllanthus amarus. Evidence for interaction with platelet activating factor receptor," European Journal of Pharmacology, vol. 546, no. 1-3, pp. 182-188, 2006.

[21] S. Sahni, S. Maurya, and U. P. Singh, "Antifungal activity of norsecurinine against some phytopathogenic fungi," Mycobiology, vol. 33, no. 2, pp. 97-103, 2005.

[22] P. J. Houghton, T. Z. Woldemariam, S. O’Shea, and S. P. Thyagarajan, "Two securinega-type alkaloids from Phyllanthus amarus," Phytochemistry, vol. 43, no. 3, pp. 715-717, 1996.

[23] H. Ali, P. J. Houghton, and A. Soumyanath, " $\alpha$-Amylase inhibitory activity of some Malaysian plants used to treat diabetes; with particular reference to Phyllanthus amarus," Journal of Ethnopharmacology, vol. 107, no. 3, pp. 449-455, 2006.

[24] D. O. Moronkola, I. A. Ogunwande, I. O. Oyewole, K. Husnu Can Başer, T. Ozek, and G. Ozek, "Studies on the volatile oils of momordica charantia L. (Cucurbitaceae) and Phyllanthus amarus Seh. et Thonn (Euphorbiaceae)," Journal of Essential Oil Research, vol. 21, no. 5, pp. 393-399, 2009.

[25] B. Ahmed, S. Khan, and A. Verma, "Antihepatotoxic activity of debelalactone, a new oxirano-furanocoumarin from Phyllanthus debilis," Journal of Asian Natural Products Research, vol. 11, no. 8, pp. 687-692, 2009.
[26] A. K. Tripathi, R. K. Verma, A. K. Gupta, M. M. Gupta, and S. P. S. Khanuja, "Quantitative determination of phyllanthin and hypophyllanthin in Phyllanthus species by high-performance thin layer chromatography," Phytochemical Analysis, vol. 17, no. 6, pp. 394-397, 2006.

[27] T. Sebastian and O. H. Setty, "Protective effect of P. fraternus Against ethanol-induced mitochondrial dysfunction," Alcohol, vol. 17, no. 1, pp. 29-34, 1999.

[28] A. A. Sittie, E. Lemmich, and C. E. Olsen, "Alkamides from Phyllanthus fraternus," Planta Medica, vol. 64, no. 2, pp. 192-193, 1998.

[29] D. S. Bhakuni, "Chemical examination of the seed of Phyllanthus maderaspatensis Linn," Journal of Scientific and Industrial Research B, vol. 18, pp. 446-447, 1959.

[30] Y.-L. Huang, C.-C. Chen, F.-L. Hsu, and C.-F. Chen, “Two tannins from Phyllanthus tenellus," Journal of Natural Products, vol. 61, no. 4, pp. 523-524, 1998.

[31] S.-H. Fang, Y. K. Rao, and Y.-M. Tzeng, "Anti-oxidant and inflammatory mediator's growth inhibitory effects of compounds isolated from Phyllanthus urinaria," Journal of Ethnopharmacology, vol. 116, no. 2, pp. 333-340, 2008.

[32] C.-C. Chang, Y.-C. Lien, K. C. S. C. Liu, and S.-S. Lee, "Lignans from Phyllanthus urinaria," Phytochemistry, vol. 63, no. 7, pp. 825-833, 2003.

[33] C.-Y. Wang and S.-S. Lee, "Analysis and identification of lignans in Phyllanthus urinaria by HPLC-SPE-NMR," Phytochemical Analysis, vol. 16, no. 2, pp. 120-126, 2005.

[34] T. Okuda, K. Mori, and T. Hatano, “The distribution of geraniin and mallotusinic acid in the order geraniales," Phytochemistry, vol. 19, no. 4, pp. 547-551, 1980.

[35] Q. Q. Yao and C. X. Zuo, "Chemical studies on the constituents of Phyllanthus urinaria L," Acta Pharmaceutica Sinica, vol. 28, no. 11, pp. 829-835, 1993.

[36] H. Luo, L. Chen, Z. Li, Z. Ding, and X. Xu, "Frontal immunoaffinity chromatography with mass spectrometric detection: a method for finding active compounds from traditional Chinese herbs," Analytical Chemistry, vol. 75, no. 16, pp. 3994-3998, 2003.

[37] M. S. Shin, E. H. Kang, and Y. I. Lee, "A flavonoid from medicinal plants blocks hepatitis $B$ virus-e antigen secretion in HBV-infected hepatocytes," Antiviral Research, vol. 67, no. 3, pp. $163-168,2005$.

[38] L. Jikai, H. Yue, T. Henkel, and K. Weber, “One step purification of corilagin and ellagic acid from Phyllanthus urinaria using high-speed countercurrent chromatography," Phytochemical Analysis, vol. 13, no. 1, pp. 1-3, 2002.

[39] T. K. Nara, J. Glyeye, E. L. Cerval et al., "Flavonoids of Phyllanthus niruri, Phyllanthus urinaria, Phyllanthus orbiculatus," Plantes Médicinales et Phytothérapie, vol. 11, pp. 82-86, 1977.

[40] K. S. Satyan, A. Prakash, R. P. Singh, and R. S. Srivastava, "Phthalic acid bis-ester and other phytoconstituents of Phyllanthus urinaria," Planta Medica, vol. 61, no. 3, pp. 293-294, 1995.

[41] Y.-L. Huang, C.-C. Chen, F.-L. Hsu, and C.-F. Chen, "A new lignan from Phyllanthus virgatus," Journal of Natural Products, vol. 59, no. 5, pp. 520-521, 1996.

[42] Y.-L. Huang, C.-C. Chen, F.-L. Hsu, and C.-F. Chen, “Tannins, flavonol sulfonates, and a norlignan from Phyllanthus virgatus," Journal of Natural Products, vol. 61, no. 10, pp. 1194-1197, 1998.

[43] H. Chirdchupunseree and P. Pramyothin, "Protective activity of phyllanthin in ethanol-treated primary culture of rat hepatocytes," Journal of Ethnopharmacology, vol. 128, no. 1, pp. 172-176, 2010. 
[44] A. Islam, T. Selvan, U. K. Mazumder, M. Gupta, and S. Ghosal, "Antitumour effect of Phyllanthin and Hypophyllanthin from Phyllanthus amarus against Ehrlich Ascites Carcinoma in mice," Pharmacologyonline, vol. 2, pp. 796-807, 2008.

[45] K. B. Harikumar, G. Kuttan, and R. Kuttan, "Inhibition of viral carcinogenesis by Phyllanthus amarus," Integrative Cancer Therapies, vol. 8, no. 3, pp. 254-260, 2009.

[46] A. Mazumder, A. Mahato, and R. Mazumder, "Antimicrobial potentiality of Phyllanthus amarus against drug resistant pathogens," Natural Product Research, vol. 20, no. 4, pp. 323326, 2006.

[47] H. Joshi and M. Parle, "Evaluation of antiamnestic potentials of [6]-gingerol and phyllanthin in mice," Natural Products, vol. 2, pp. 109-117, 2006.

[48] A. D. Kandhare, P. Ghosh, A. E. Ghule et al., "Protective effect of Phyllanthus amarus by modulation of endogenous biomarkers and DNA damage in acetic acid induced ulcerative colitis: role of phyllanthin and hypophyllanthin," Apollo Medicine, vol. 10, no. 1, pp. 87-97, 2013.

[49] D. F. P. Leite, C. A. L. Kassuya, T. L. Mazzuco et al., "The cytotoxic effect and the multidrug resistance reversing action of lignans from Phyllanthus amarus," Planta Medica, vol. 72, no. 15, pp. 1353-1358, 2006.

[50] H. Dhir, A. Kumar Roy, A. Sharma, and G. Talukder, "Protection afforded by aqueous extracts of Phyllanthus species against cytotoxicity induced by lead and aluminium salts," Phytotherapy Research, vol. 4, no. 5, pp. 172-176, 1990.

[51] F. Notka, G. Meier, and R. Wagner, "Concerted inhibitory activities of Phyllanthus amarus on HIV replication in vitro and ex vivo," Antiviral Research, vol. 64, no. 2, pp. 93-102, 2004.

[52] J. S. Londhe, T. P. A. Devasagayam, L. Y. Foo et al., "Geraniin and amariin, ellagitannins from Phyllanthus amarus, protect liver cells against ethanol induced cytotoxicity," Fitoterapia, vol. 83, no. 8, pp. 1562-1568, 2012.

[53] M. Ogunlesi, W. Okiei, E. A. S. Osibote, and C. Muotoh, "Antimicrobial activity of the essential oil and the fractional samples obtained from the leaves and seeds of Phyllanthus atnarus (Euphorbiaceae)," Research Journal of Phytochemistry, vol. 3, no. 4, pp. 77-84, 2009.

[54] S. H. Lee, I. B. Jaganath, S. M. Wang, and S. D. Sekaran, "Antimetastatic effects of Phyllanthus on human lung (A549) and breast (MCF-7) cancer cell lines," PLoS ONE, vol. 6, no. 6, article e20994, 2011.

[55] C.-M. Yang, H.-Y. Cheng, T.-C. Lin, L.-C. Chiang, and C.-C. Lin, "The in vitro activity of geraniin and 1,3,4,6-tetra-Ogalloyl- $\beta$-d-glucose isolated from Phyllanthus urinaria against herpes simplex virus type 1 and type 2 infection," Journal of Ethnopharmacology, vol. 110, no. 3, pp. 555-558, 2007.

[56] S.-Y. Lin, C.-C. Wang, Y.-L. Lu, W.-C. Wu, and W.-C. Hou, "Antioxidant, anti-semicarbazide-sensitive amine oxidase, and anti-hypertensive activities of geraniin isolated from Phyllanthus urinaria," Food and Chemical Toxicology, vol. 46, no. 7, pp. 2485-2492, 2008.

[57] S.-T. Huang, C.-Y. Wang, R.-C. Yang et al., "Ellagic acid, the active compound of Phyllanthus urinaria, exerts in vivo antiangiogenic effect and inhibits MMP-2 activity," Evidence-Based Complementary and Alternative Medicine, vol. 2011, Article ID 215035, 10 pages, 2011.

[58] S. S. Handa, A. S. Chawla, and A. K. Sharma, "Plants with antiinflammatory activity," Fitoterapia, vol. 63, no. 1, pp. 3-31, 1992.
[59] A. R. S. Santos, V. C. Filho, R. A. Yunes, and J. B. Calixto, "Analysis of the mechanisms underlying the antinociceptive effect of the extracts of plants from the genus Phyllanthus," General Pharmacology, vol. 26, no. 7, pp. 1499-1506, 1995.

[60] M. C. Recio, R. M. Giner, S. Manez, and J. L. Rios, "Structural requirements for the anti-inflammatory activity of natural triterpenoids," Planta Medica, vol. 61, no. 2, pp. 182-185, 1995.

[61] M. Maruyama, S. Yamauchi, K. Akiyama, T. Sugahara, T. Kishida, and Y. Koba, "Antibacterial activity of a virgatusinrelated compound," Bioscience, Biotechnology and Biochemistry, vol. 71, no. 3, pp. 677-680, 2007.

[62] J. R. Patel, P. Tripathi, V. Sharma, N. S. Chauhan, and V. K. Dixit, "Phyllanthus amarus: ethnomedicinal uses, phytochemistry and pharmacology: a review," Journal of Ethnopharmacology, vol. 138, no. 2, pp. 286-313, 2011.

[63] C. P. Kala, P. P. Dhyani, and B. S. Sajwan, "Developing the medicinal plants sector in northern India: challenges and opportunities," Journal of Ethnobiology and Ethnomedicine, vol. 2, article 32, 2006.

[64] P. S. Udayan, K. V. Tushar, S. George et al., "Ethnomedicinal information fron Kattunayakas tribes of Mudumalai Wildlife Sanctuary. Nilgiris district, Tamil Nadu," Indian Journal of Traditional Knowledge, vol. 6, pp. 574-578, 2007.

[65] R. P. Samy, P. N. Pushparaj, and P. A. Gopikrishnakone, "Compilation of bioactive compounds from Ayurveda," Bioinformation, vol. 3, no. 3, pp. 100-110, 2008.

[66] K. Chenniappan and M. Kadarkarai, "In vitro antimalarial activity of traditionally used Western Ghats plants from India and their interactions with chloroquine against chloroquineresistant Plasmodium falciparum," Parasitology Research, vol. 107, no. 6, pp. 1351-1364, 2010.

[67] B. Upadhyay, P. Parveen, A. K. Dhaker, and A. Kumar, "Ethnomedicinal and ethnopharmaco-statistical studies of Eastern Rajasthan, India," Journal of Ethnopharmacology, vol. 129, no. 1, pp. 64-86, 2010.

[68] A. Jain, S. S. Katewa, P. K. Galav, and P. Sharma, "Medicinal plant diversity of Sitamata wildlife sanctuary, Rajasthan, India," Journal of Ethnopharmacology, vol. 102, no. 2, pp. 143-157, 2005.

[69] P. Mahishi, B. H. Srinivasa, and M. B. Shivanna, "Medicinal plant wealth of local communities in some villages in Shimoga District of Karnataka, India," Journal of Ethnopharmacology, vol. 98, no. 3, pp. 307-312, 2005.

[70] C. Muthu, M. Ayyanar, N. Raja, and S. Ignacimuthu, "Medicinal plants used by traditional healers in Kancheepuram District of Tamil Nadu, India," Journal of Ethnobiology and Ethnomedicine, vol. 2, article 43, 2006.

[71] S. Ignacimuthu, M. Ayyanar, and K. Sankarasivaraman, "Ethnobotanical study of medicinal plants used by Paliyar tribals in Theni district of Tamil Nadu, India," Fitoterapia, vol. 79, no. 7-8, pp. 562-568, 2008.

[72] S. Shanmugam, K. Maniknandan, and K. Rajendran, "Ethnomedicinal survey of medicinal plants used for the treatment of diabetes and jaundice among the villagers of Sivagangai District, Tamil Nadu," Ethnobotanical Leaflets, vol. 13, no. 1, pp. 189-194, 2009.

[73] N. Rajakumar and M. B. Shivanna, "Ethno-medicinal application of plants in the eastern region of Shimoga district, Karnataka, India," Journal of Ethnopharmacology, vol. 126, no. 1, pp. 64-73, 2009.

[74] J. K. Samuel and B. Andrews, "Traditional medicinal plant wealth of Pachalur and Periyur hamlets Dindigul district, Tamil 
Nadu," Indian Journal of Traditional Knowledge, vol. 9, no. 2, pp. 264-270, 2010.

[75] K. B. Hari Kumar and R. Kuttan, "Inhibition of drug metabolizing enzymes (cytochrome P450) in vitro as well as in vivo by Phyllanthus amarus Schum \& Thonn," Biological and Pharmaceutical Bulletin, vol. 29, no. 7, pp. 1310-1313, 2006.

[76] K. S. Chandrashekar, A. B. Joshi, D. Satyanarayana, and P. Pai, "Analgesic and anti-inflammatory activities of Phyllanthus debilis whole plant," Pharmaceutical Biology, vol. 43, no. 7, pp. 586-588, 2005.

[77] V. Acharya, V. Sharma, P. K. Patra et al., "Plants used by Kamar, Gond and Halba tribe of Dhamtari district of Chhattisgarh for relief of sickle cell disease," Recent Research in Science and Technology, vol. 4, no. 3, pp. 1-3, 2012.

[78] K. K. Wanniarachchi, L. D. C. Peiris, and W. D. Ratnasooriya, "Antihyperglycemic and hypoglycemic activities of Phyllanthus debilis aqueous plant extract in mice," Pharmaceutical Biology, vol. 47, no. 3, pp. 260-265, 2009.

[79] A. Kumaran and R. Joel Karunakaran, "In vitro antioxidant activities of methanol extracts of five Phyllanthus species from India," LWT-Food Science and Technology, vol. 40, no. 2, pp. 344-352, 2007.

[80] J. L. Nishiura, A. H. Campos, M. A. Boim, I. P. Heilberg, and N. Schor, "Phyllanthus niruri normalizes elevated urinary calcium levels in calcium stone forming (CSF) patients," Urological Research, vol. 32, no. 5, pp. 362-366, 2004.

[81] S. Chanda, M. Kaneria, and Y. K. Vaghasiya, "Evaluation of antimicrobial potential of some Indian medicinal plants against some pathogenic microbes," Indian Journal of Natural Products and Resources, vol. 2, no. 2, pp. 225-228, 2011.

[82] R. Sailaja and O. H. Setty, "Protective effect of Phyllanthus fraternus against allyl alcohol-induced oxidative stress in liver mitochondria," Journal of Ethnopharmacology, vol. 105, no. 1-2, pp. 201-209, 2006.

[83] S. Gopi and O. H. Setty, "Protective effect of Phyllanthus fraternus against bromobenzene induced mitochondrial dysfunction in rat liver mitochondria," Food and Chemical Toxicology, vol. 48, no. 8-9, pp. 2170-2175, 2010.

[84] K. K. Kumari and O. H. Setty, "Protective effect of Phyllanthus fraternus against mitochondrial dysfunction induced by coadministration of cisplatin and cyclophosphamide," Journal of Bioenergetics and Biomembranes, vol. 44, no. 1, pp. 179-188, 2012.

[85] G. A. Koffuor and P. Amoateng, "Antioxidant and anticoagulant properties of Phyllanthus fraternus GL Webster (Family: Euphorbiaceae)," Journal of Pharmacology and Toxicology, vol. 6, no. 7, pp. 624-636, 2011.

[86] V. I. Hukeri, G. A. Kalyani, and H. K. Kakrani, "Hypoglycemic activity of flavonoids of Phyllanthus fraternus in rats," Fitoterapia, vol. 59, no. 1, pp. 68-70, 1988.

[87] S. P. Thyagarajan, S. Jayaram, V. Gopalakrishnan, R. Hari, P. Jeyakumar, and M. S. Sripathi, "Herbal medicines for liver diseases in India," Journal of Gastroenterology and Hepatology, vol. 17, no. 3, pp. S370-S376, 2002.

[88] V. V. Asha and P. Pushpangadan, "Preliminary evaluation of the antihepatotoxic activity of Phyllanthus kozhikodianus, $P$. maderaspatensis and Solanum indicum," Fitoterapia, vol. 69, no. 3, pp. 255-259, 1998.

[89] M. J. N. Chandrasekar, P. Bommu, M. J. Nanjan, and B. Suresh, "Chemoprotective effect of Phyllanthus maderaspatensis in modulating cisplatin-induced nephrotoxicity and genotoxicity," Pharmaceutical Biology, vol. 44, no. 2, pp. 100-106, 2006.
[90] P. Bommu, C. M. J. Nanjan, N. M. Joghee, S. M. Nataraj, and S. Bhojraj, "Phyllanthus maderaspatensis, a dietary supplement for the amelioration of adriamycin-induced toxicity and oxidative stress in mice," Journal of Natural Medicines, vol. 62, no. 2, pp. 149-154, 2008.

[91] V. V. Asha, S. Akhila, P. J. Wills, and A. Subramoniam, "Further studies on the antihepatotoxic activity of Phyllanthus maderaspatensis Linn," Journal of Ethnopharmacology, vol. 92, no. 1, pp. 67-70, 2004.

[92] V. Sivajothi, A. Dey, B. Jayakar, and B. Rajkapoor, "Antihyperglycemic, antihyperlipidemic and antioxidant effect of Phyllanthus rheedii on streptozotocin induced diabetic rats," Iranian Journal of Pharmaceutical Research, vol. 7, no. 1, pp. 5359, 2008.

[93] V. Suresh and V. V. Asha, "Preventive effect of ethanol extract of Phyllanthus rheedii Wight. on d-galactosamine induced hepatic damage in Wistar rats," Journal of Ethnopharmacology, vol. 116, no. 3, pp. 447-453, 2008.

[94] S. R. N. Ignácio, J. L. P. Ferreira, M. B. Almeida, and C. F. Kubelka, "Nitric oxide production by murine peritoneal macrophages in vitro and in vivo treated with Phyllanthus tenellus extracts," Journal of Ethnopharmacology, vol. 74, no. 2, pp. 181-187, 2001.

[95] D. F. Oliveira, A. C. Pereira, H. C. P. Figueiredo et al., "Antibacterial activity of plant extracts from Brazilian southeast region," Fitoterapia, vol. 78, no. 2, pp. 142-145, 2007.

[96] A. R. S. Santos, V. C. Filho, R. Niero et al., "Analgesic effects of callus culture extracts from selected species of Phyllanthus in mice," Journal of Pharmacy and Pharmacology, vol. 46, no. 9, pp. 755-759, 1994.

[97] T. C. D. L. Silva, F. J. Veras, I. A. Souza et al., "Acute toxicity study of stone-breaker (Phyllanthus tenellus Roxb.)," Revista de Ciências Farmacêuticas Básica e Aplicada, vol. 33, no. 2, pp. 205210, 2012.

[98] S.-T. Huang, R.-C. Yang, and J.-H. S. Pang, "Aqueous extract of Phyllanthus urinaria induces apoptosis in human cancer cells," American Journal of Chinese Medicine, vol. 32, no. 2, pp. 175-183, 2004.

[99] S.-T. Huang, J.-H. S. Pang, and R.-C. Yang, "Anti-cancer effects of Phyllanthus urinaria and relevant mechanisms," Chang Gung Medical Journal, vol. 33, no. 5, pp. 477-487, 2010.

[100] Y.-Q. Tang, I. B. Jaganath, and S. D. Sekaran, "Phyllanthus spp. induces selective growth inhibition of PC-3 and MeWo human cancer cells through modulation of cell cycle and induction of apoptosis," PloS ONE, vol. 5, no. 9, article e12644, 2010.

[101] M. Zhong, Y. Xiang, X. Qiu et al., "Natural products as a source of anti-herpes simplex virus agents," RSC Advances, vol. 3, no. 2, pp. 313-328, 2013.

[102] C. A. Lans, "Ethnomedicines used in Trinidad and Tobago for urinary problems and diabetes mellitus," Journal of Ethnobiology and Ethnomedicine, vol. 2, article 45, 2006.

[103] C.-H. Lai, S.-H. Fang, Y. K. Rao et al., "Inhibition of Helicobacter pylori-induced inflammation in human gastric epithelial AGS cells by Phyllanthus urinaria extracts," Journal of Ethnopharmacology, vol. 118, no. 3, pp. 522-526, 2008.

[104] V. J. Tiwari and M. D. Padhye, "Ethnobotanical study of Gond tribe of Chandrapur and Gadchiroli districts of Maharashtra State, India," Fitoterapia, vol. 64, no. 1, pp. 58-61, 1993.

[105] K. Poompachee and N. Chudapongse, "Comparison of the antioxidant and cytotoxic activities of Phyllanthus virgatus and Phyllanthus amarus extracts," Medical Principles and Practice, vol. 21, no. 1, pp. 24-29, 2012. 
[106] S. K. Sharma, S. M. Arogya, D. H. Bhaskarmurthy, A. Agarwal, and C. C. Velusami, "Hepatoprotective activity of the Phyllanthus species on tert-butyl hydroperoxide $(t-\mathrm{BH})$-induced cytotoxicity in HepG2 cells," Pharmacognosy Magazine, vol. 7, no. 27, pp. 229-233, 2011.

[107] R. Murugan, R. R. Rao, and V. Vishwanatha, "Occurrence of Phyllanthus scabrifolius Hook. f. in Amingad, Bagalkot district, Karnataka-a new distributional record," Current Science, vol. 91, no. 7, pp. 870-871, 2006.

[108] S. Khatoon, V. Rai, A. K. S. Rawat, and S. Mehrotra, "Comparative pharmacognostic studies of three Phyllanthus species," Journal of Ethnopharmacology, vol. 104, no. 1-2, pp. 79-86, 2006.

[109] R. Srirama, H. B. Deepak, U. Senthilkumar et al., "Hepatoprotective activity of Indian Phyllanthus," Pharmaceutical Biology, vol. 50, no. 8, pp. 948-953, 2012.

[110] M. Palaniappan and M. Marappa, "RAPD and ISSR analyses reveal low levels of genetic diversity in Phyllanthus amarus," in Proceedings of the 27th International Horticultural CongressIHC, International Symposium on Plants as Food and Medicine: The Utilization and Development of Horticultural Plants for Human Health, ISHS Acta Horticulture 765, 2006.

[111] N. Jain, A. K. Shasany, V. Sundaresan et al., "Molecular diversity in Phyllanthus amarus assessed through RAPD analysis," Current Science, vol. 85, no. 10, pp. 1454-1458, 2003.

[112] R. L. Mitra and S. K. Jain, "Concept of Phyllanthus niruri (Euphorbiaceae) in Indian floras," Bulletin of the Botanical Survey of India, vol. 27, no. 1-4, pp. 161-176, 1985.

[113] B. S. Geetha, K. K. Sabu, and S. Seeni, "Genetic variation in South India populations of Phyllanthus amarus Schum \& Thonn. (Euphorbiaceae) assessed using isozymes," in Proceedings of the 15th Kerala Science Congress, pp. 196-201, 2003.

[114] G. Ravikant, R. Srirama, U. Senthilkumar et al., "Genetic resources of Phyllanthus in Southern India: identification of geographic and genetic hot spots and its implication for conservation," in Phyllanthus Species: Scientific Evaluation and Medicinal Applications, R. Kuttan and K. B. Harikumar, Eds., pp. 97-118, Taylor and Francis Group, CRC Press, London, UK, 2011.

[115] D. Kandavel, S. K. Rani, M. G. Vinithra et al., "Systematic studies in herbaceous Phyllanthus spp. (region: Tiruchirappalli district in India) and a simple key to authenticate 'Bhumyamalaki'complex members," Journal of Phytology, vol. 3, no. 2, pp. 37-48, 2011.

[116] G. L. Webster, "A monographic study of the West Indian species of Phyllanthus," Journal of the Arnold Arboretum, vol. 38, pp. 295-373, 1957.

[117] N. Jain, A. K. Shasany, S. Singh, S. P. S. Khanuja, and S. Kumar, "SCAR markers for correct identification of Phyllanthus amarus, $P$. fraternus, $P$. debilis and $P$. urinaria used in scientific investigations and dry leaf bulk herb trade," Planta Medica, vol. 74, no. 3, pp. 296-301, 2008.

[118] P. Theerakulpisut, N. Kanawapee, D. Maensiri, S. Bunnag, and P. Chantaranothai, "Development of species-specific SCAR markers for identification of three medicinal species of Phyllanthus," Journal of Systematics and Evolution, vol. 46, no. 4, pp. 614-621, 2008.

[119] S. Bandyopadhyay and S. S. Raychaudhuri, "Development and comparison of RAPD, SCAR and AFLP markers for distinguishing some medicinally important species of the genus Phyllanthus," Plant Biosystems, vol. 147, no. 1, pp. 12-20, 2013.

[120] S. K. Senapati, S. Aparajita, and G. R. Rout, "Identification of species-diagnostic inter simple sequence repeat markers for ten
Phyllanthus species," Zeitschrift fur Naturforschung C, vol. 66, no. 3-4, pp. 167-172, 2011.

[121] R. Srirama, U. Senthilkumar, N. Sreejayan et al., "Assessing species admixtures in raw drug trade of Phyllanthus, a hepatoprotective plant using molecular tools," Journal of Ethnopharmacology, vol. 130, no. 2, pp. 208-215, 2010.

[122] J. Manissorn, S. Sukrong, N. Ruangrungsi, and H. Mizukami, "Molecular phylogenetic analysis of Phyllanthus species in Thailand and the application of polymerase chain reactionrestriction fragment length polymorphism for Phyllanthus amarus identification," Biological and Pharmaceutical Bulletin, vol. 33, no. 10, pp. 1723-1727, 2010.

[123] S. Bandyopadhyay and S. S. Raychaudhuri, "Development of ITS based SCAR markers for some medicinally important species of Phyllanthus," Asian Journal of Plant Sciences, vol. 9, no. 5, pp. 264-270, 2010.

[124] G. R. Rout, S. K. Senapati, and S. Aparajita, "Study of relationships among twelve Phyllanthus species with the use of molecular markers," Czech Journal of Genetics and Plant Breeding, vol. 46, no. 3, pp. 135-141, 2010. 

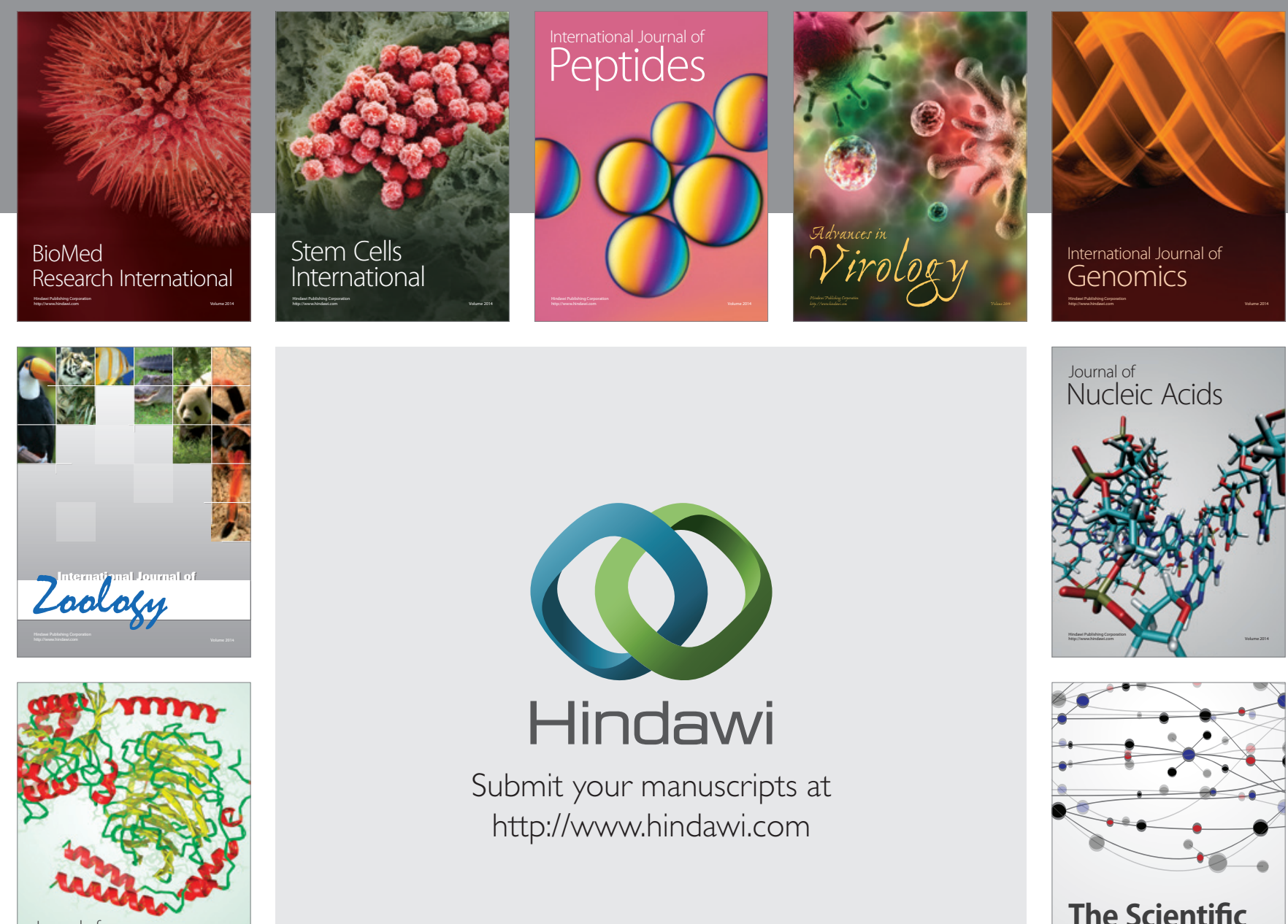

Submit your manuscripts at

http://www.hindawi.com

Journal of
Signal Transduction
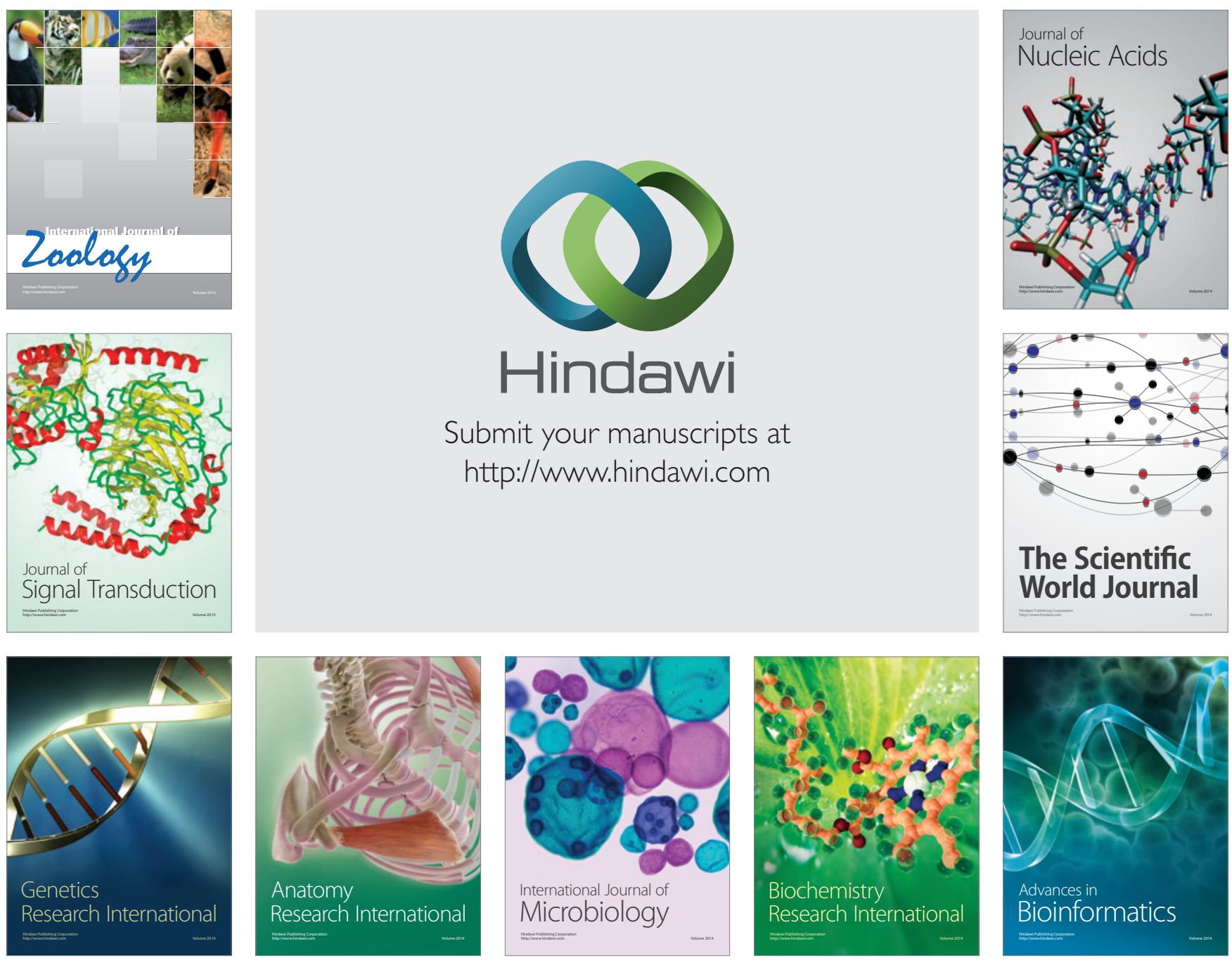

The Scientific World Journal
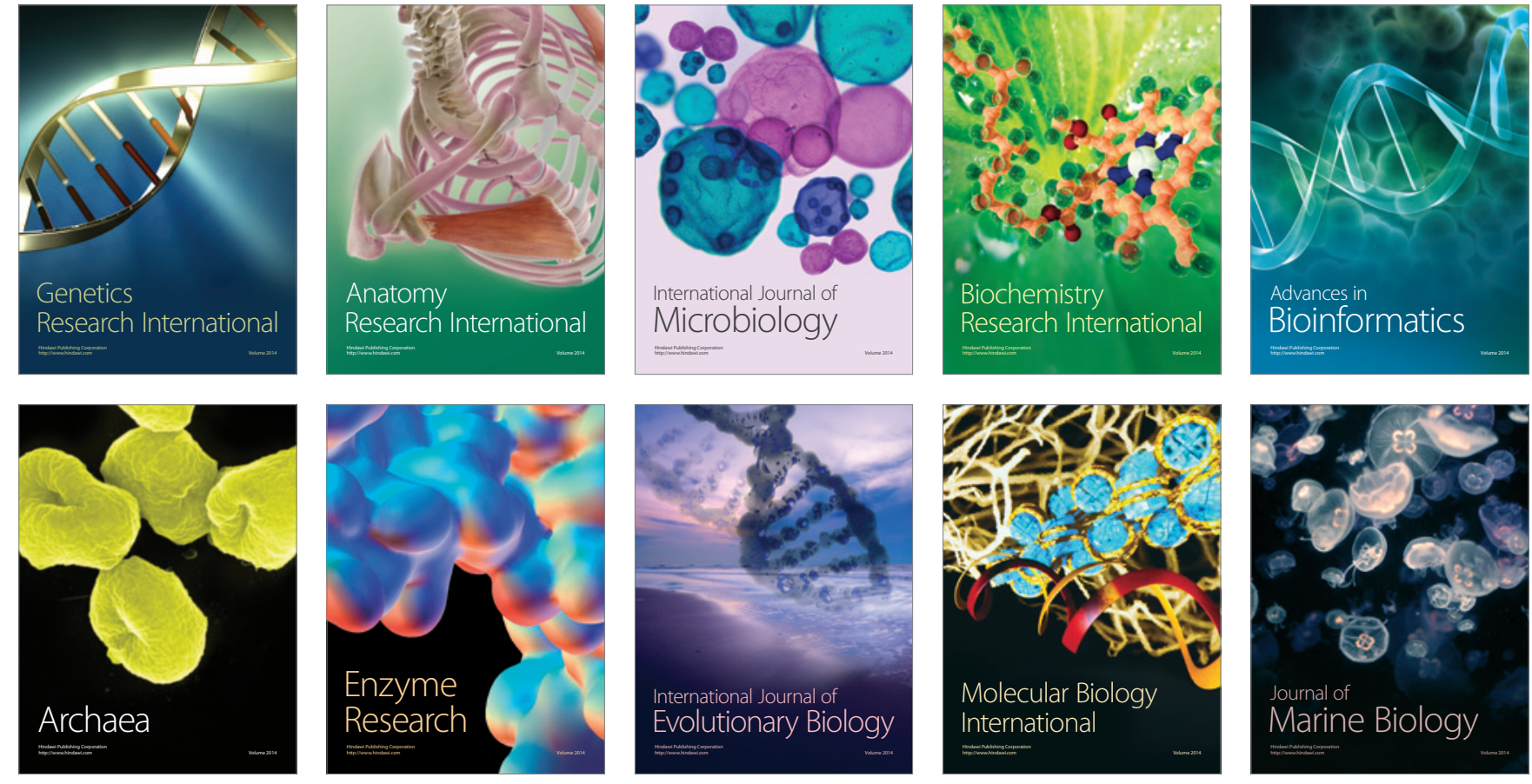